TEACHING TUVAN LANGUAGE TO JAPANESE LEARNERS

\section{ВОПРОСЫ ПРЕПОДАВАНИЯ ТУВИНСКОГО ЯЗЫКА ЯПОНЦАМ}

Kaori Sawada

Independent author, Japan,

Katsuhiko Kurosawa

Independent author, Japan
Каори Савада

Независимый автор, Япония,

Кацухико Куросава

Независимый автор, Япония

One author of this article (Kaori Sawada) lived in the Republic of Tuva and studied Tuvan throat singing (xöomei) and Tuvan language from 2011 to 2017. She is an interpreter between Tuvan and Japanese languages, currently teaching Tuvan in Japan. The fans of
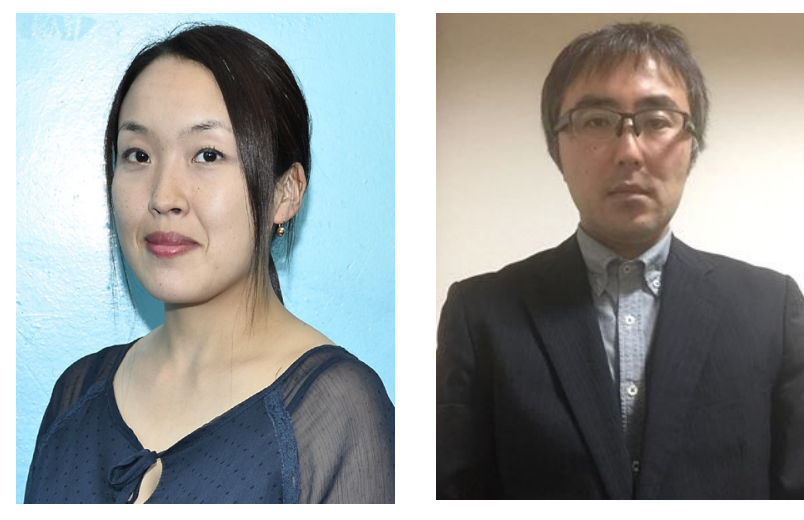

Один из авторов этой статьи Каори Савада с 2011 по 2017 22. проживала в Республике Тыва, изучала горловое пение тувинцев (хӧӧтеі) $u$ тувинский язык. Изучив язык, стала работать в Японии переводчиком тувинско-японского языка и преподавать тувинский язык. Отмечается, что японцы проявляют интерес к тувинской культуре, но прилагают мало усилий для Tuvan culture in Japan are holding their interests since 2011, however, the numbers of Japanese people making their efforts to study Tuvan language are few. The purpose of this article is to discuss the problems and the reactions of the students during the teaching practices of Tuvan language in Japan and to share our opinions, referring to this author's experience of studying Tuvan language in the Tuvan State University, about the solution of the problems, effective systems and learning materials.

The article also presents the outcomes of a survey of Japanese studying Tuvan language. The questionnairebased survey was held in December 2017 on Facebook

изучения тувинского языка. Целью данной статьи является обсуждение проблем и реакций студентов на практику преподавания тувинского языка в Японии, а также со ссылкой на авторский опыт изучения тувинского языка в Тувинском государственном университете на решение проблем, эффективные методики и учебные материалы.

В статье приведены данные опроса японцев, обучающихся тувинскому языку. Анкетный опрос проводился для них в декабре 2017 2. в социальной сети Facebook с целью прояснения сложных моментов по изучению тувинского языка в Япо-

Kaori Sawada, Independent Autor, Teacher of Tuvan language, Tuvan interpreter, Japan. E-mail: kaorikk570@gmail.com

Katsuhiko Kurosawa, Independent Autor; corporate employee, Nippon C.C.L. Inc., Japan. E-mail: seikei. kurosawa@gmail.com

Каори Савада - независимый автор; учитель тувинского языка, переводчик, Япония. Эл. адрес: kaorikk570@gmail.com

Катсухико Куросава - независимый автор; служащий Nippon C.C.L. Inc., Япония. Эл. адрес: seikei. kurosawa@gmail.com 
aimed to clarify some of the complexities faced by Japanese students of Tuvan. Of the 8 respondents, all were fans of xöomei and musicians who were highly interested in Tuvan culture. They could be seen as potential popularizers of Tuvan culture in Japan. The authors provide examples of difficulties the Japanese students of Tuvan can face and explain the reasons for these problems.

The article concludes with a number of practical recommendations on how to make teaching Tuvan language to Japanese learners more efficient.

Keywords: Tuvan language; Japan; teaching of the Tuvan language; Japanese; xöömei; grammar of the Tuvan language; methods of teaching нии. Респондентов было 8 чел., все любители хоомея, музыканты, которые имеют сильную заинтересованность в тувинской культуре, $u$ которых можно рассматривать как популяризаторов тувинской культуры в Японии. Автор приводит примеры трудностей, с которыми сталкиваются японские слушатели курсов и анализирует причины этих трудностей.

Завершают статью практические рекомендации по эффективному обучению японцев тувинскому языку.

Ключевые слова: тувинский язык; Япония; преподавание тувинского языка; японцы; хоомей; грамматика тувинского языка; методика преподавания

\section{Introduction}

Tuvan culture has been fascinating Japanese fans for over 30 years.

In 1985, Gennadi Tumat, the legendary xöömei singer, arrived in Japan and played at the music festival concert in Hokkaido (Oorzhak, 2012: 104). Since his visit to Japan in 1985, many xöömei singers have been invited and played in Japan, and they have been attracting Japanese audiences.

In recent years, Huun Huur Tu had the concert tour in Japan on 2012, and they played concerts at Hyogo, Shizuoka and Tokyo. In 2014, they were invited to Fuji Rock Festival which is the biggest rock 'n roll festival in Japan and had a concert (Huun Huur Tu, 2014: online). In this time, they put on a concert in Tokyo too (Huun Huur $\mathrm{Tu}$... 2014: online).

In March 2017, concerts named “Xöömei Paradise” were organize in Tokyo (http:// biyoyon.umizoko.com). Mrs. Choduraa Tumat was invited to the event from the Republic of Tuva and played with Japanese xöömei singers and groups. There were large audiences at the event, so some had to stand behind the back-row seats at the concerts. In November 2017, Mr. Andrei Mongush and Mr. Andrei Opei were invited to Japan and had concerts and workshops at Nagano and Tokyo (Concert, 2017: online). The strong interest for Tuvan culture in Japan was confirmed by the success of these events. Many Japanese musicians and xöömei fans have been visiting the Republic of Tuva every year and attending the xöomei concerts and festivals. Most of them have learned xöömei from Tuvan xöömeizhi at the workshops, and some of them are expanding their playing field as Japanese xöömeizhi in Japan (Terada, 2017: online; Tadagawa, 2017: online).

On the other hand, Tuvan language currently has a low profile among Japanese learners, including Japanese xöömei singers. I served as an interpreter during the events and helped the communications between Tuvan and Japanese people. 
The concert staffs and the audiences had strong interest in Tuvan culture so that I translated Tuvan and Japanese languages many times. But there were very few times when Japanese people would talk directly in Tuvan language to the Tuvan guests. This phenomenon can be contrasted to the cases that many Japanese fans have been speaking in English to English-language singers visiting to Japan.

One author of this article lived in Tuva for 6 years from 2011, and has been teaching Tuvan language to Japanese learners from 2017. From this experience, Tuvan language is not hard to learn for Japanese people but there are still some difficult points. However, the fact that there are fans of xöomei in Japan suggests that Japanese people are likely to accept the voice of Tuvan people. To clarify the difficult points of learning Tuvan language for Japanese people, learners should be provided with a clue of further understanding of Tuvan culture and xöomei. The purpose of this article is to discuss the problems and the reactions of the students during the teaching practices of Tuvan language in Japan and to share our opinions, referring to the experience of studying Tuvan language in the Tuvan State University, about the solution to these problems, effective systems and learning materials.

\section{Historical Background of Learning Foreign Language by Japanese People}

Historically, Japanese people have been very tolerant for foreign languages and have actively adopted foreign words to Japanese language.

In the ancient times, Japanese writing did not have original characters. "Kanji," the Chinese ideogram, have been used in documents since around the 5th or 6th centuries in Japan. "Hiragana," the phonogram characters simplified kanji characters, was invented around the 9th century. Japanese people have been using "kanji" and "hiragana" characters for writing Japanese sentences. "Katakana" was also invented at about the same times. Katakana was mainly used for the annotation of Chinese sentences or poems in the middle ages, and for foreign characters representing pronunciation of foreign words in recent times too. Tuvan music words (ex. xöömei, khomusu and igil) are usually written in katakana in Japanese.

In 1962, the National Institute for Japanese Language and Linguistics showed that 60 Japanese magazines contained about 410,000 words, which they classified as being $37 \%$ of Japanese origin, $47 \%$ of Chinese origin, $10 \%$ of katakana originated from Western European language and 6\% of mixture words (Kashiwabara, 2012). This result shows that more than half of the Japanese words originated from foreign languages.

Since 19th century, Japanese government and companies tried to catch up with the social system and culture of European countries, and they invited many foreigners and hired them as teachers or trainers in various fields, including language, in Japan. 
The "hired foreigners" used texts written in their homeland, i. e. in foreign languages. But Japanese educators and students actively translated them into Japanese, and they brought new words into their language and created mixture words in the course of translation. Many foreign texts are translated into Japanese now, and Japanese teachers generally use them at class. Compared to the problem that university educators in many countries are compelled to use the texts written in the western languages with their students, the educational catching-up from modern ages in Japan was a success for the localization of knowledge (Funahashi, 2015).

\section{Learning of Foreign Language by Japanese People in Modern times}

Even in modern times, many Japanese people are learning foreign languages enthusiastically. There are commonly some foreign language schools near the big railway station in Japan. According to the survey held by the Japanese government (Ministry of Economy, Trade and Industry, 2002), the number of foreign language conversation schools is about 1,200, with about 25,000 lecturers, and over 1 million students, respectively. $40,0 \%$ of the students are teenagers, $26,2 \%$ are in their twenties and $17,2 \%$, in their thirties. Most of the students, as can be seen, are of young and active age. However, the languages learned in the classes are mostly Western European: 92,9\%, English, 18,3\%, French and 10,8\%, German.

\section{General difficulties of learning Tuvan language by Japanese people}

There are two main patterns of coming to learn Tuvan language for Japanese people. Some Japanese researchers studying the linguistics and the folklore on the Eurasian continent recognize Tuvan as one of the Turkic languages. The Japanese audiences attending the concerts of xöömei singers recognize Tuvan as the language of the lyrics. Many fans of Tuvan culture came to Tuvan language in the latter way because xöömei has a certain profile in Japan. Teaching Tuvan language associated with xöömei should have potential demand in Japan. However, there are some difficulties of learning Tuvan language for Japanese people.

Japanese people are not accustomed to Cyrillic letters or have never used them. There are so many foreign language expressions on the streets of Japan, but most of them are in English and used is the Roman alphabet. Many Japanese people cannot convert the lyrics sung in non-Western European language to the words of the country. This is one of the reasons why only a few xöömei fans know Tuvan language in Japan.

There are very few books on Tuva published in Japan. The books by M. Todoriki (Todoriki, 2000) and Takashima (Dambaa, Takashima, 2008; Takashima, 2008ab) are devoted to Tuvan language but the main target of them is not the general public. Takashima and Dambaa (Takashima, Dambaa, 2008) and Nakajima (Nakajima, 2008) 
published Tuvan-Japanese dictionaries, however, a Japanese-Tuvan dictionary has never appeared in Japan. K. A. Bischeldei published a speaking text book of Tuvan language with $\mathrm{CD}$ of Tuvan conversation by The Tuva Trader but they withdrew from the market (Bicheldei, 1995).

There are very few liner notes of Tuvan music CDs with Tuvan lyrics and Japanese translations. This phenomenon is limited to CDs of English singers. Music CDs sung in English are very popular in Japan though their prices are about 1.5 to 2 times higher than the imported ones. It is because the record companies in Japan generally add the liner notes in English and translated lyrics. These liner notes are one of the great pleasures of English song fans. Tuvan music CDs including Huun Huur Tu are also distributed in the Japanese music market, but the optional booklet with the lyrics translated into Japanese are not attached to most CDs.

Sometimes xöömei workshops held by Tuvan xöömeizhis or Japanese xöömei singers have been held in Japan, and Japanese people may have attended and learned the voice methods of xöömei. Though they would like to try to sing the same song as the xöömeizhi, they can only sing by dictation because of the absence of translated lyrics. Opportunities for Japanese xöömei fans to learn the culture of Tuvan lyrics are quite small in Japan.

There are very few lecturers who can teach Tuvan in Japan. Currently there are only a few Japanese who can speak Tuvan, and only a few Tuvans living in Japan. Japanese people cannot easily get to hear a conversation in Tuvan. It is not easy to improve listening comprehension and Tuvan speaking skills in Japan.

\section{Questionnaire survey about the Tuvan class}

One of the authors of this article (Sawada) teaches Tuvan language to Japanese audiences. About half of the students have learned in the classroom, and the other students have studied via the telecommunication service. A questionnaire survey has been held for them in order to clarify the difficult points for learning Tuvan language in Japan. All questionees are xöömei fans or musicians and they have a strong interest in Tuvan cultures. They may be the evangelists of Tuvan cultures in Japan.

The survey period was from 10 to 18 December 2017 via the questionnaire option on Facebook. The questionees are 8 students. The queries and the results are as followes.

The questionees have the incentive to learn Tuvan language, not only other foreign languages $(\mathrm{Q} 7)$. The result of $\mathrm{Q} 2$ suggests that they have already had classes of foreign languages in Japan. This indicates that there may the potential demand for learning system of Tuvan language in Tuva. 
Table 1. The queries and the results of the questionnaire about the Tuvan class Таблица 1. Вопросы и результаты анкетирования слушателей тувинского класса.

1 Are you female or male?

2 Which language have you learned except English? (multiple answers allowed)

3 Do you like Tuvan clultures (including Tuvan language)?

4 When did you first learn of Tuvan culture and language?

5 What was your first encounter with Tuvan language?

6 Why do you want to lean Tuvan language?

7 What level do you want to achieve?

8 What is the most difficult point to write in Tuvan language?

9 What is the most difficult point to speak in Tuvan language?

10 What is the most difficult point to learn Tuvan grammers?

11 Do you want to practice speaking Tuvan with the native speaker?

12 Do you want to visit to the Republic of Tuva and learn Tuvan language?

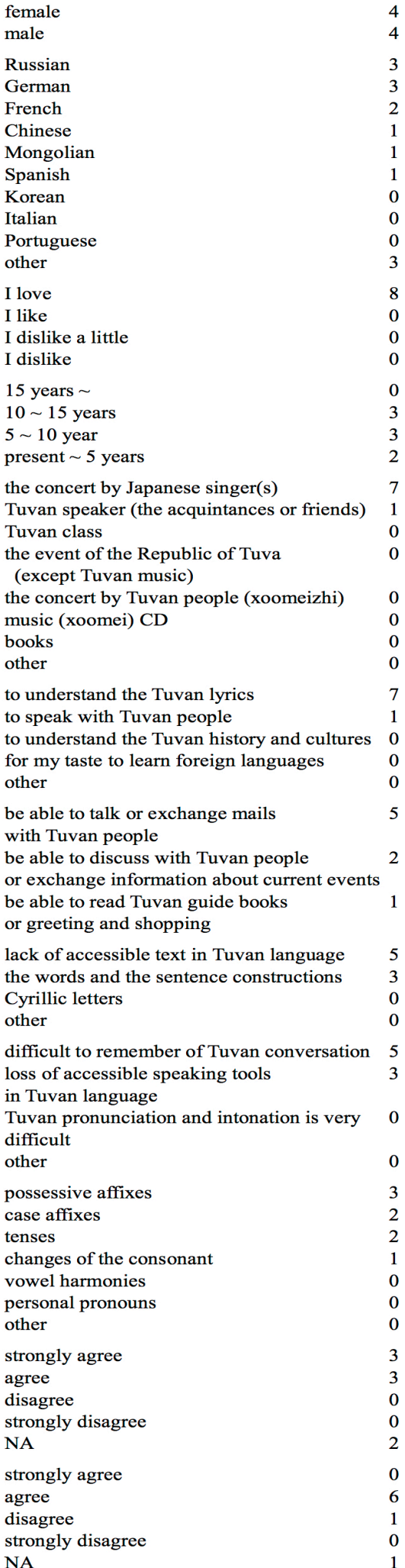


The link between xöömei and Tuvan language is strong in Japan (Q5 and 6). The main motivators for the interest in Tuvan language are Japanese xöömei singers for the questionees (Q6). They have been continuously interested in xöömei songs for years $(\mathrm{Q} 4)$ and that shows the attraction of Tuvan culture.

There were some optional comments for this survey. A questionee of this survey suggested that there are no accessible texts in Tuvan language and learning tools for speaking Tuvan. Another commenter showed the difficulty of communication in Tuvan because of the lack of Japanese-Tuvan dictionary.

Regarding grammar, there were many answers about the differences between Tuvan and Japanese grammars (Q10). For example, Japanese people don't easily get the sense of attaching possessive affix to the noun, because there is no possessive affix in Japanese. Japanese people must learn many affix rules of the Tuvan language.

\section{Difficulties of learning Tuvan language in the Republic of Tuva for Japanese people}

Japanese fans of xöömei and Tuvan cultures would like to visit the Republic of Tuva and learn about it someday. One of the authors (Sawada) also encountered xöömei in 2005 and wanted to go someday to the Republic of Tuva. She visited the Republic of Tuva for the first time in 2009 and started learning Tuvan language. She came back to Japan and learnt Tuvan by reading books in the language. She entered Tuvan State University in 2011 to study the language professionally. But there were some difficulties for her.

Those were the difficulties arising from the absence of organized programs for teaching Tuvan language to foreigners in the Republic of Tuva. If the foreigners would lean Tuvan language from their Tuvan acquaintances, they could not obtain official diplomas. The foreigners hoping to learn Tuvan language must enter Tuvan State University under the same educational program as native speakers do. Furthermore, if you do not understand Russian language to a certain extent, you will not be able to keep up with the classes held in Russian.

When Sawada entered Tuvan State University, she was able to engage in everyday conversation in Tuva. But she could not write letters with cursive writing quickly. She borrowed the notes from the classmates afterwards because she could not write the content of the lecture. Her reading speed was also slow, and it was very hard for her to finish the assigned class reading on time.

Some of the difficulties came due to the differences between Tuvan and Japanese educational methods. She did not know the learning methods to draw lines under the sentences studied in the classes, and she could not understand the classification method of the sentence elements at first. 


\section{Easy and difficult points of learning Tuvan grammar for Japanese people}

Tuvan language is classified as one of the Turkic languages, while Japanese is regarded as a language in a category of its own. From the middle of the 20th century, some linguists have studied the similarities between Japanese and the continental Eurasian language groups (Turkish, Mongolian, Tungus, Korean and Altai languages) and hypothesized that Japanese belongs to the group of Altai languages (Sravnitel'noistoricheskaia grammatika ..., 1988; Dybo, 1996).

Japanese and Altai languages are classified as agglutinative languages, and this common feature makes learning them easier. By attaching an affix to the words, it is possible to express the grammatical relation in the sentence. The case affixes of Tuvan and Japanese are 7 and 10 species, respectively. In both languages, case affixes are used to express relationship.

Nominative case - Ga case: tuv. $a$ z $m=\varnothing /$ jp. $u m a=g a$

Genitive case - No case: tuv. кщжи=ниң / jp. hito=no

Dative case $-\mathrm{Ni}$ case: tuv. хем=ге / jp. kawa $=n i$

Accusative case $-\mathrm{O}$ case: tuv. ном $=$ ну / jp. $h o n=0$

Locative case - De case: tuv. Бажың=дa / jp. ie=de

Ablative case - Kara case: tuv. тей=ден / jp. oka=kara

Directional case - E case: tuv. хоорай=же / jp. machi=e

The relationships and meanings expressed by the case affixes in Tuvan language correspond to those in Japanese (Savada, 2016).

The word orders in both languages is SOV. For example, the Tuvan sentence of "Акира Тываже барган" and its translated version "Akira=ga Tuva=e ikimashita" in Japanese have SOV word order. Therefore, replacing the words and the affixes in Japanese sentences with those of Tuvan language is one of the shortest ways of translating from Japanese to Tuvan.

One of the difficult point of Tuvan grammar for Japanese people is that the vocabularies of both languages have little in common. The Tuvan vocabulary has been influenced by Turkic, Mongolian and Russian, while Japanese, by English and Chinese. Some words of Tuvan and Japanese are derived from Chinese (Ondar, 2008). For example, чанчын - General (shougun), самбың - abacus (soroban), лаa - wax (rou). However, the Tuvan words originated from Chinese are few and their origin is hard to recognize in the modern time.

There are phonetic differences between the two languages. The Tuvan vowels of $\theta, \gamma, b$ have no equivalents in Japanese and only $y$. Pronouncing those sounds is very difficult for Japanese learners. An author of this article (Sawada) managed to 
learn their pronunciation, but it is still difficult for her to write down the words as pronounced by native speakers of Tuvan because the vowels are difficult to classify. There is nо л in Tuvan phonetics but only only $p$ or the middle pronunciation between $\pi$ and $p$. Those distinctions of the pronunciations are difficult for Japanese people, and the Tuvan word including both "hard spots" (ех. байырлыг, олурар, арзылаң) are difficult for Japanese learners. In Japanese, consonants are always followed by vowels and there are no words ending with consonants. Especially the words which last letters are $2, m$ or $n$ are quite difficult to pronounce for Japanese people, and they often pronounce чылыг as чылыгы, дидим - дидиму, чөвп - чөзпу.

The languages with pharyngealized vowels are very few in the world. The vowels are difficult to pronounce for not only Japanese but also the other foreigners. The pronunciation of the Tuvan words which have pharyngealized vowels, such as кижи, blm and $\mathrm{kыm}$, have never been adequately described for the lack of the pronunciation symbols. The foreigners had to hear and learn the pronunciation by Tuvan native speakers. K. A. Bicheldei (Bicheldey, 2011) annotated the hard-to-pronounce signs, such as pharyngealized vowels, and those annotations are very useful to learn the pronunciation of Tuvan words for the foreigners. Толковый словарь тувинского языкa (Tolkovyi slovar' ..., 2003, 2011) is also useful for foreigners because the words pronounced with a pharyngeal vowel are annotated with [ъ].

The vowel harmonies are not used in Japanese language. The Tuvan pronunciation has very reasonable rules but those are hard to understand for the foreigners. The affixes varied by the vowel harmonies are difficult to understand too.

In Tuvan, words usually have stress on their last syllable, but the accent of Japanese words depends on the word.

\section{The ideas of the educational tools for learning Tuvan language by Japanese people}

From the experience of learning Tuvan language as a Japanese learner and teaching it to Japanese, we propose the following materials as educational tools:

- an accessible text book. Visual contents (e. g., illustrations or photographs of objects of Tuvan culture) may be very useful for Japanese students. The grammar explanations, words, exercises and columns should be accompanied by this visual content. The collection of the conversation examples in Tuvan for each situation would also be helpful for Japanese students. The collection should also contain audio materials with recordings of the voices of native speakers, and those materials will be effective for foreign students;

- a collection of the Tuvan lyrics translated into Japanese. It must explain the meaning of Tuvan songs and illustrate the singer's interpretations, which will make it also interesting for Japanese fans of Tuvan cultures. A Japanese-Tuvan dictionary 
and a textbook of Tuvan syntax should also be published for Japanese students of Tuvan;

- lectures and videos on Tuvan conversation distributed via the Internet. Tuvan lecturers in Japan are quite few, and the number of students and the locations of the classroom are limited. The lecturing system via the Internet could solve both problems. Lectures by native speakers would be useful to improve pronunciation of foreign learners;

- organizing programs of learning Tuvan language for the foreigners. To increase motivation for them to learn Tuvan, a certificate of Tuvan language command has to be introduced. It is necessary to develop Tuvan textbooks for the foreigners and lecturers who can teach Tuvan using foreign languages such as English as an intermediary.

\section{Acknowledgments}

We would like to express my gratitude to Mr. Masahiko Ishiya who recommended us for contributing to this journal and provided a lot of guidance and advice. Also, We express my sincere gratitude to everyone who participated in the Tuva course and took part in the survey. One of the few Tuvan people living in Japan, O. A. Oyun corrected the Tuvan and Russian in my article. We thank you here.

\section{REFERENCES}

Bicheldei, K. A. (1995) Let's Learn Tuvan! Scientific Consulting Services, July. 62 p.

Bicheldei, K. A. (2011) Sai dashta sagysh-se"tkil khonashtary (Amydyral, ki"zhi, $o$ "rtemchei du"gaiynda bodaldarym dalaiyndan) [Thoughts on stone stelae of native lands (the Ocean of my thoughts about life, man and the Universe]. Abakan. 392 p. (In Tuv.).

Concert [コンサート] (2017). Chaa records [on-line] Available at: http://chaa. jp/?page_id=17 (accessed: 10.01.2018). (In Japanese).

Dambaa O.V. [ダンバー O.V]. and Takashima H. [高島 尚生] (2008). トゥバ語会話 集 [Tuvan-Japanese PhraseBook]. 東京外国語大学, 86. Tokyo University of Foreign Studies. 86. (In Japanese).

Dybo, A. V. (1996) Semanticheskaia rekonstruktsiia $v$ altaiskoi etimologii: : somaticheskie terminy (plechevoi poyas) [Semantic Reconstruction in the Altaic Etymology: Somatic Terms (Shoulder Girdle)]. Moscow, Rossiiskaia akademiia nauk institut iazykoznaniia. 385 p. (In Russ.).

Funahashi (2015) Kensho nihon no ushinawareta 20 nen: Nihon ha Naze Teitai kara nukedasenakattanoka [The Verification - Japan's lost 20 years]. 156 p. (In Japanese). 
Huun Huur $\mathrm{Tu}$ (2014). Fujirock Express 2014 [online] Available at: http:// fujirockexpress.net/14e/p_2335 (access: 12.01.2018).

Huun Huur Tu （フーン フール トゥ）来日公演 (2014). Toppan Hall, Jule 24 [online] Available at: http://www.toppanhall.com/concert/detail/201407241900. html (access: 12.01.2018). (In Japanese).

Kashiwabara S. (2012) Role of Chinese Words in Japanese And Korean. Bulletin of the Faculty of Education, Wakayama University, Humanities, no. 63 [on-line] Available at: http://dx.doi.org/10.19002/AN00257999.63.195 (accessed: 10.01.2018).

Ministry of Economy, Trade and Industry (2002): II. "Gaikokugo kaiwa kyoushitsu no gaikyo. Meti.go.jp [online] Available at: http://www.meti.go.jp/statistics/tyo/ tokusabizi/result-2/h14/pdf/h14-t-27.pdf (In Japanese).

Nakajima, Y. (2008). Tuvan language terminology [トゥバ語小辞典]. 東京外国語大 学 [Tokyo University of Foreign Studies]. (In Japanese).

Ondar, A. (2008) Tyva dylda kydat dyldan ylegerleeshkinner [Chinese Loanwords in Tuvan language]. Ertem bizhikteri. Kyzyl, TuvGU. Pp. 8-15. (In Tuv.).

Oorzhak, O. (2012) Tyva chonnuњ khөөmeizhizi Khaidyp oglu Gennadii Tumat [Folk Khoomeizhi of the Republic of Tuva Hidup oglu Gennady Tumat]. Kyzyl, Mezhdunarodnyi Nauchnyi tsentr Khoomei. (In Tuv.).

Savada, K. (2016) Tyva bolgash iapon dyldarda chyve attaryny grammatiktig kategoriiazynyң deңnelgezi [The comparison of grammatical categories of the noun in Tuvan and Japanese]. Kyzyl, TuvGU. 112 p. (In Tuv.).

Sravnitel'no-istoricheskaia grammatika tiurkskikh iazykov [Comparative-historical grammar of Turkic languages] (1988) / ed. by E. R. Tenishev. Moscow, Nauka. 560 p. (In Russ.).

Tadagawa, L. (2017) The khomus is my red deer on which I fly through the middle world (Khomus in the shamanic practice of Tuva: Research issues). The New Research of Tuva, no. 2 [on-line] Available at: 1https://nit.tuva.asia/nit/article/view/718 (accessed: 10.01.2018). DOI: 10.25178/nit.2017.2.7

Takashima, H. [高島 尚生] (2008b). Touba language textbooks [トゥバ語教本]. 東京 外国語大学 [Tokyo University of Foreign Studies], 141. (In Japanese).

Takashima, H. [高島 尚生] and Dambaa O. V. (2008). Touba French classified vocabulary [トゥバ語分類語彙集]. 東京外国語大学 [Tokyo University of Foreign Studies], 137. (In Japanese).

Takashima, H. [高島 尚生] (2008a). The basis Touba English grammar [基礎トゥ バ語文法]. 東京外国語大学 [Tokyo University of Foreign Studies], 254. (In Japanese).

Terada, M. (2017) Razvitie sovremennoi muzykal'noi kul'tury Tuvy (vzgliad iz Iaponii) [The development of contemporary music culture of Tuva (a view from 
Japan)]. The New Research of Tuva, no. 2 [on-line] Available at: https://nit.tuva.asia/ nit/article/view/707 (accessed: 10.01.2018). DOI: 10.25178/nit.2017.2.11 (In Russ.).

Todoriki, M. (2000) Let's sing in Tuvan language! - A private grammar text of Tuvan language for throat singers [トゥバ語で歌おう! 喉歌歌手のためのーちょっ と不親切なトゥバ語文法ノート (トゥバ語の歌詞付き]. 私家版, 91. (In Japanese).

Tolkovyi slovar' tuvinskogo iazyka [Dictionary of the Tuvan language] (2003) / ed. by D. A. Mongush. Novosibirsk, Nauka. Vol. I (A-И). 597 p.

Tolkovyi slovar' tuvinskogo iazyka [Dictionary of the Tuvan language] (2011) / ed. by D. A. Mongush. Novosibirsk, Nauka. Vol. II (K-C). 796 p. (In Russ. and Tuv.).

Submission date: 15.01.2018.

\section{СПИСОК ЛИТЕРАТУРЫ}

Bicheldei, K. A. (1995) Let's Learn Tuvan! Scientific Consulting Services, July 1995. $62 \mathrm{p}$.

Dambaa O. V. [ダンバー・ O. V.], Takashima [高島 尚生] (2008). Тыва-япон чугаa ному [トゥバ語会話集]. 東京外国語大学 [Токийский университет иностранных исследований]. 86 с. (На яп. яз.).

Funahashi (2015) Kensho nihon no ushinawareta 20 nen: Nihon ha Naze Teitai kara nukedasenakattanoka. 156 p. (In Japanese).

Huun Huur Tu (2014) [Электронный ресурс] // Fugirock Express 2014. URL: http://fujirockexpress.net/14e/p_2335 (дата обращения: 12.01.2018).

Huun Huur Tu (フーン フール トゥ) 来日公演 (2014) [Электронный peсурс] // Toppan Hall, 24 июля. URL: http://www.toppanhall.com/concert/ detail/201407241900.html (дата обращения: 12.01.2018). (На яп. яз.).

Kashiwabara S. (2012) Role of Chinese Words in Japanese And Korean [Электронный ресурс] // Bulletin of the Faculty of Education, Wakayama University, Humanities, no. 63 URL: http://dx.doi.org/10.19002/AN00257999.63.195 (дата обращения: 10.01.2018).

Ministry of Economy, Trade and Industry (2002): II. “Gaikokugo kaiwa kyoushitsu no gaikyo [Электронный ресурс] // Meti.go.jp URL: http://www.meti.go.jp/statistics/tyo/ tokusabizi/result-2/h14/pdf/h14-t-27.pdf (дата обращения: 12.01.2018). (На яп. яз.).

Nakajima, Y. (2008). Терминология тувинского языка [トゥバ語小辞典]. 東京外 国語大学 [Tokyo University of Foreign Studies]. (На яп. яз.).

Tadagawa, L. (2017) The khomus is my red deer on which I fly through the middle world (Khomus in the shamanic practice of Tuva: Research issues) [Электронный ресурс] // Новые исследования Тувы. № 2. URL: 1https://nit.tuva.asia/nit/article/ view/718 (дата обращения: 10.01.2018). DOI: 10.25178/nit.2017.2.7 
Takashima [高島 尚] (2008a). Основы тувинско-английской грамматики [基礎 トゥバ語文]. 東京外国語大学 [Токийский университет иностранных исследований], 254. (На яп. яз.).

Takashima H. [高島 尚生] (2008b). Учебник тувинского языка [トゥバ語教本]. 東京 外国語大学 [Токийский университет иностранных исследований], 141. (На яп. Яз.).

Takashima H. [高島 尚生], Dambaa O. V. (2008) Тыва-япон лексиктиг словарь [トゥバ語分類語彙集].東京外国語大学 [Токийский университет иностранных исследований], 137. (На тув. и яп. яз.).

Todoriki, M. (2000) Давайте споем на тувинском! Для певца горлового пения: немного недобросовестная тетрадь грамматики тувинского языка (с лирикой тувинцев) [トゥバ語で歌おう！喉歌歌手のための-ちょっと不親切なトゥバ語文法 ノート (トゥバ語の歌詞付き )]. 私家版 [Частное издание], 91. (На яп. яз.).

Бичелдей, К. А. (2011) Сай дашта сагыш-сеъткил хонаштары (Амыдырал, киъжи, өъртемчей дуъгайында бодалдарым далайындан) [«Мысли на каменных стелах родных кочевий (Океан моих мыслей о жизни, человеке и Вселенной»]. Абакан. 392 с.

Дыбо, А. В. (1996) Семантическая реконструкция в алтайской этимологии. Соматические термины (плечевой пояс). М. : Российская академия наук институт языкознания. 385 с.

Концерт [コンサー] (2017) [Электронный ресурс] // Chaa records. URL: http:// chaa.jp/?page_id=17 (дата обращения: 10.01.2018). (На яп. яз.).

Ондар, А. (2008) Тыва дылда кыдат дылдан үлегерлээшкиннер // Эртем бижиктери. Кызыл: ТувГУ. С. 8-15. (На тув. яз.).

Ооржак, О. (2012) Тыва чоннуң хөөмейжизи Хайдып оглу Геннадий Тумат. Кызыл: Международный Научный центр Хоомей. (На тув. яз.).

Савада, К. (2016) Тыва болгаш япон дылдарда чүве аттарының грамматиктиг категориязының деңнелгези. Кызыл : ТувГУ. 112 с. (На тув. яз.).

Сравнительно-историческая грамматика тюркских языков (1988) / под ред. Э. Р. Тенишева. М. : Наука. 560 с.

Терада, М. (2017) Развитие современной музыкальной культуры Тувы (взгляд из Японии) [Электронный ресурс] // Новые исследования Тувы. № 2.URL: https:// nit.tuva.asia/nit/article/view/707 (дата обращения: 10.01.2018). DOI: 10.25178/ nit.2017.2.11

Толковый словарь тувинского языка (2003) / под ред. Д. А. Монгуша. Новосибирск : Наука. Т. I (А-Й). 597 с.

Толковый словарь тувинского языка (2011) / под ред. Д. А. Монгуша. Новосибирск: Наука. Т. II (К-С). 796 с. 


\section{Для цитирования:}

Sawada K., Kurosawa K. Teaching Tuvan Language to Japanese Learners [Электронный ресурс] // Новые исследования Тувы. 2018, № 1. URL: https://nit.tuva.asia/nit/ article/view/758 (дата обращения: дд.мм.гг.). DOI: 10.25178/nit.2018.1.8

\section{For citation:}

Sawada K. and Kurosawa K. Teaching Tuvan Language to Japanese Learners. The New Research of Tuva, 2018, no. 1 [on-line] Available at: https://nit.tuva.asia/nit/article/view/758 (accessed: ... ). DOI: 10.25178/nit.2018.1.8 